\title{
A 19th Century New Ireland Dog, Canis familiaris novaehiberniae Lesson, 1827 and the Status of Canis hallstromi Troughton, 1957
}

\author{
Peter D. Dwyer ${ }^{1}$, Harry E. Parnaby ${ }^{2}$, and Monica Minnegal ${ }^{3}{ }^{-6}$ \\ ${ }^{1}$ School of Geography, Earth and Atmospheric Sciences, \\ University of Melbourne, Parkville VIC 3010, Australia \\ ${ }^{2}$ Australian Museum Research Institute, \\ Australian Museum, 1 William Street, Sydney NSW 2010, Australia \\ ${ }^{2}$ School of Social and Political Sciences, \\ University of Melbourne, Parkville VIC 3010, Australia
}

\begin{abstract}
Recent literature has usually invoked the name Canis hallstromi Troughton, 1957, though with varied taxonomic interpretations, when writing of dogs thought to be unique to New Guinea. The name Canis familiaris novaehiberniae was proposed for dogs from the New Guinea region 130 years before Troughton published Canis hallstromi but has been overlooked in the recent literature, as has Canis familiaris papuensis Ramsay, 1879 from southeastern New Guinea. The taxonomic status of New Guinea dogs remains controversial but if dogs from New Guinea and New Ireland represent a single heterogeneous gene pool, then $C$. hallstromi Troughton and C. familiaris papuensis Ramsay would be junior subjective synonyms of C. familiaris novaehiberniae Lesson, 1827. Recent studies of New Guinea dogs are weakened by their failure to attend carefully to the history of discovery and nomenclature of these animals.
\end{abstract}

\section{Introduction}

The New Guinea region comprises mainland New Guinea and nearby islands, together with the Bismarck Archipelago (New Ireland and New Britain) and the northwestern Solomon Islands (Bougainville and Buka). European visitors to coastal locations, from as early as 1606 , often reported the presence of dogs, their tendency to howl rather than bark, the use of their teeth to make necklaces and the fact that their flesh was eaten (Jukes, 1847; Moresby, 1874-1875; Stevens, 1930; Miklouho-Maclay, 1975). As Europeans commenced exploring inland New Guinea, dogs were commonly reported as village animals and sometimes, particularly at high altitudes above the tree line, as feral or wild-living animals (Morton, 1885; Macgregor, 1892-1893; Murray, 1912; Strong, 1919: 300).
Through the mid- and late 1900s, and the first decade of the 2000s, there have been occasional reports of wild-living dogs from New Guinea, all from high altitudes (Flannery \& Seri, 1990; McIntyre et al., 2019). Some authors assert that these wild-living dogs are a unique type that, though at risk of extinction in the wild, survive as a captive population held and bred in the United States of America since the late 1950s (Koler-Matznick et al., 2003, 2007). That interpretation does not acknowledge earlier records of wild-living dogs from low altitudes of mainland New Guinea and from New Britain and the Solomon Islands. Nor does it address the apparent absence of wild-living dogs from low and middle altitude areas that are dominated by rainforest but sparsely populated. ${ }^{1}$

The most recent accounts of New Guinea dogs focus on animals either from the USA captive population or from a 
population of wild-living dogs found in the vicinity of the Grasberg mine in the Indonesian province of Papua (KolerMatznick et al., 2005; McIntyre et al., 2019). Genetic studies have shown that the captive population was derived from a population like that of the Papuan wild-living dogs and that these, together with dingoes, qualify as a distinct, perhaps ancient, lineage of dogs (Surbakti et al., 2020). These studies attribute taxonomic recognition of New Guinea dogs to Troughton who in 1957 proposed the name Canis hallstromi for what he considered a distinct species.

In this paper we draw attention to the facts that, $(a) 130$ years before Troughton proposed the name $C$. hallstromi, dogs from the New Guinea region had been named as Canis familiaris novaehiberniae by the naturalist RenéPrimevère Lesson (1827a) and $(b)$ the overlooked name Canis familiaris papuensis Ramsay, 1879 is not invalid as proposed by Troughton and could displace Canis hallstromi. Although C.f. novaehiberniae Lesson has been recognized in the taxonomic literature since the mid-19th century (e.g., Laurillard, 1849; Studer, 1901; Werth, 1944), recent literature referring to dogs thought to be unique to the New Guinea region has more often used Canis hallstromi.

\section{Ramsay's dog}

In 1879, Ramsay (1879: 242) had proposed that "the dogs used by [Papuan] natives" be named Canis familiaris var. papuensis. Miklouho-Maclay (1881: 625) adapted this usage in referring to New Guinea village dogs as Canis papuensis but most subsequent taxonomists have overlooked the name. Ramsay's description was based, in part, on examination of a single specimen that was in a "very bad state" and, according to Troughton (1971: 96), "evidently was destroyed". However, a skull attributable to this specimen was recently rediscovered in the Australian Museum collection, where it had been registered as A.3652 in December 1878 and by subsequent determination was reported as the holotype (Parnaby et al., 2017: 345; their use of "designated" was an error). The precise type locality of this dog is not known but, based on available reports by Morton (1885), is likely to be in the hinterland of Port Moresby, near Laloki River (Fig. 1).

Troughton (1957: 94) considered papuensis to be an invalid name (a nomen nudum) but gave no reasons for this. His opinion was made without the benefit of the International Code of Zoological Nomenclature (ICZN, 1999; hereafter the Code), first published in 1961. Ramsay states that his description, which included size, colour and vocalization, drew from the field notes of the collectors A. Morton and $\mathrm{K}$. Broadbent in addition to the poorly preserved specimen. Although inadequate by modern standards, Ramsay's brief description included alleged diagnostic criteria and fulfills requirements of Article 12.1 (the Code) as an available name. It is therefore not a nomen nudum.

Ramsay (1879: 242) introduced his description with the words: "The dogs used by the natives are of various colors, usually yellowish with short ears, and small brushy tail". He was describing village dogs, not feral or wild dogs. Morton's (1885) reflections support this:

Although we did not find them in a wild state, a word must be said about the New Guinea dogs. Every house possesses several, that somewhat resemble the Australian dingo, and like them, do not bark, but howl. When one howls, even though it be the dead of night, it is a point of honour for all the others to howl for company, until the noise transcends all description.

Though some authors contend that, in New Guinea, chorus howling is found only in high altitude wild-living dogs (Surbakti et al., 2020), vocalizations of this kind have been reported from the earliest European encounters with coastal and inland village dogs in New Guinea (see Dwyer \& Minnegal, 2016: 7). Jackson \& Groves (2015: 288) suggest that "papuensis may refer to feral dogs", but provide no evidence for this.

\section{Troughton's dog}

In March 1957, two dogs were shipped from Lae, in the Australian Mandated Territory of New Guinea, to Taronga Zoological Park in Sydney. They were reported to be a "wild dog and his mate, first of their kind to leave the territory" (Anon., 1957).

Soon after their arrival at Taronga Park, the dogs were examined by Ellis Troughton, mammalogist at the Australian Museum. He considered that they represented a new species, which he named Canis hallstromi. He treated the male as holotype and the female as allotype and reported that both were "in possession of Sir Edward Hallstrom at Taronga Zoological Park, Sydney, for eventual lodgment in the collection of the Australian Museum" (Troughton, 1957: 93).

Troughton's (1957) published description of Canis hallstromi was based on examining two live animals. He mentioned "difficulties in examining and measuring the sensitive animals" but expressed confidence that future work "will ultimately confirm the validity of this primitive species" (1957: 94). In a later paper (Troughton, 1971), he reported that the male holotype and female allotype were now held by the Australian Museum (registered M.8502 and M.8917 respectively). Although he continued to use the name $C$. hallstromi in that paper, he may now have been less certain regarding the status of Ramsay's contribution for he wrote: "Whether Ramsay's name be accepted, or rejected as a nomen nudum, it has since been overlooked by all authors with the exception of Miklouho-Maclay".

In 2003, Koler-Matznick et al. published a detailed description and rediagnosis of $C$. hallstromi Troughton, 1957 that was based on museum material, referenced the types held by the Australian Museum, and made comparisons with the taxa C. familiaris Linnaeus, 1758, C. dingo Meyer, 1793 and C. lupus Linnaeus, 1758. Though acknowledging that "the taxonomic identity of [these dogs] cannot be unequivocally determined from currently available data" (2003: 116) they considered C. hallstromi- " "popularly called the New Guinea Singing Dog" - to be a distinct form of wild-living dog found at high altitudes of New Guinea where it was largely isolated from dogs found in villages at lower altitudes (see also Koler-Matznick et al., 2007). However, disagreement about the taxonomic status of New Guinea dogs continues (Crowther et al., 2014; Jackson et al., 2017; Smith et al., 2019); some treat New Guinea dogs with domestic dogs within $C$. familiaris without further taxonomic subdivision (Jackson et al., 2017) and others argue that, at the time of European colonization, village-living and wild-living dogs at all altitudes of New Guinea were members of a single intra-breeding population (Dwyer \& Minnegal, 2016; Gollan, 1982: 210-211; Williams et al., 2018: 4). 


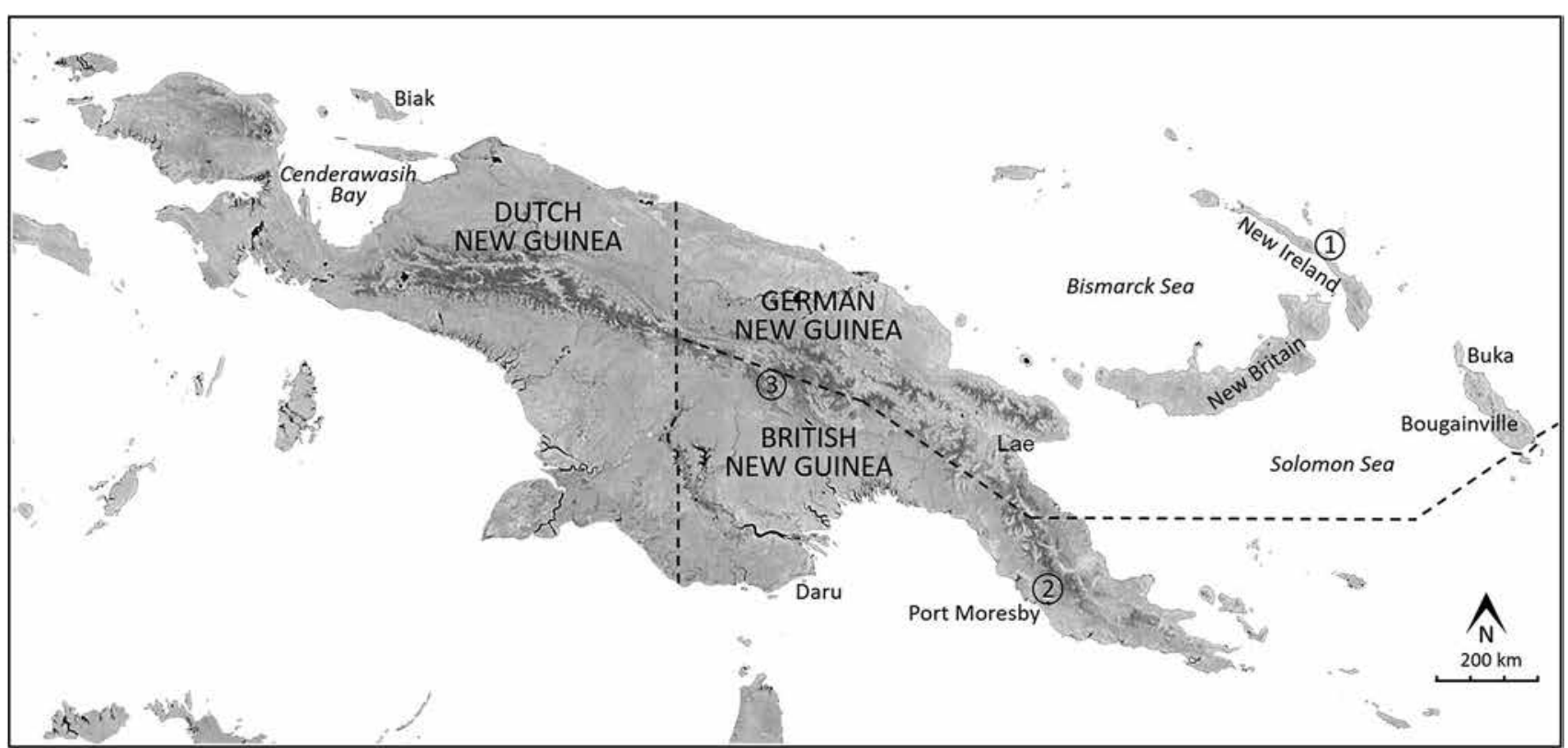

Figure 1. Map of New Guinea region showing colonial territories in the late 1800 s and type localities of: (1) Canis familiaris novaehiberniae Lesson, 1827a, New Ireland; (2) C.f. papuensis Ramsay, 1879, unspecified, southeastern New Guinea; and (3) C. hallstromi Troughton, 1957, Lavani Valley, Southern Highlands District.

\section{Lesson's dog}

In August 1822, the naturalists René-Primevère Lesson and Prosper Garnot joined Louis-Isidore Duperrey on a voyage around the world, embarking from Toulon, France, in the corvette Coquille (Lesson \& Garnot, 1826-1829). In May the following year they reached Tahiti, planning to travel southwest to Port Jackson (Australia), but were forced by the weather to stay further north. At New Ireland (Fig. 1), they observed village dogs. Lesson later wrote:

\begin{abstract}
The dogs, named Poull, are small; their muzzle is pointed, and their ears are erect. They seemed to us in everything similar to those of New Holland. Courageous and very predatory, they live off everything they encounter, including fish and crabs, which they will fish on the reefs. The natives feed on their flesh, they find it very delicate: they thought that we made the same use of those we bought alive, and which we were obliged to abandon at Port-Jackson (Lesson, 1827b: 123; translated from French).
\end{abstract}

They report dogs of the same kind from Buka and Bougainville islands (Lesson, 1827b: 132) but provide no details on the fate of the dogs abandoned at Port Jackson. From New Ireland, the Coquille travelled west, staying relatively close to the north coast of New Guinea. At one place, unnamed but presumably the Biak Islands:

\begin{abstract}
The natives of New Guinea daily brought on board the species of dog which lives in their huts, and which they call nafe. It did not differ from the dog of New Ireland, and very little from that of New Holland (Australasia). As in the latter, the coat is short, fawn or black, the muzzle tapering; the ears are straight and short, the habits bold, and the barking nil (Lesson \& Garnot, 1826: 127; translated from French).
\end{abstract}

Forty-seven years earlier, in February 1775, at "Schouten's Island" (Biak Island, Cenderawasih Bay, Indonesian Papua), Thomas Forrest saw "men getting out of their boats, with two or three fox looking dogs ... a dog they call Naf" (1782: 97).
Naf is one of two Biak names for dog listed by Voorhoeve (1975: 124), and Luomala (1960: 218) was mistaken in writing that both Forrest and Lesson had learned the name naf or nafe at Daru, on the south coast of New Guinea. In his monograph on dogs, Walther (1817: 23) drew on Forrest's account to compare the New Guinea dog with the mastiff and on that basis named it Canis familiaris villaticus var. novaeguineae. Although this appears to be the earliest Linnaean name given to a New Guinea dog, it was expressly proposed as an infrasubspecific name by Walther and is, therefore, not an available name under Articles 45.5.1 and 45.6.4 (the Code).

The Coquille sailed from the Biak Islands to the Dutch port of Amboina in the Moluccan (Maluku) Islands. After about one month, she sailed for Port Jackson via the west and south coasts of Australia before finally returning to France in March 1825.

In a handbook to the mammals of the world, Lesson (1827a: 158-159) listed varieties of domestic dogs under the heading "Canis familiaris, L." In a category of mastiff-like dogs he formally named the "dog of New Ireland" as "Canis novae-hyberniae, Lesson". His description was minimal:

This dog, half the size of Australia's, has a sharp muzzle; straight ears, pointed and short; slender legs; short hair, brown or fawn in color; named Poull by the natives who feed on its flesh; he is bold, courageous and voracious; he eats everything. (Translated from French.)

A consistently applied set of nomenclatural rules was still evolving during Lesson's time and "Canis novae-hyberniae Lesson" (Lesson, 1827a: 159), as cited by him, equates to subspecific nomenclature because he placed it as a variety under the heading "Canis familiaris L." on an earlier page.

Lesson's work was quickly adopted and influenced the interpretations of European researchers for the next century. Most subsequent 19th century authors cite Canis novaehiberniae or variants, sometimes as a species but often as a race or variety of the domestic dog; through 
this time evolutionary concepts of species, subspecies and variety were poorly defined. The citation by Fischer (1829: 180) of "Canis familiaris Novae Hiberniae" coincides with modern nomenclatural practice and his altered spelling of Lesson's "novae-hyberniae" as "novae-hiberniae" was adopted by subsequent authors and appears to be a correct emendation (Article 19.2, the Code). Schreber et al. (1841: 375) acknowledged the work of Lesson, though they treated the New Guinea dog as "Canis dingo" and did not list $C$. novaehiberniae in their synonymy. Glaire (1844: 227) and Laurillard (1849: 626) used the name "Canis NovaeHiberniae" and noted that the New Ireland dog was smaller than the dog from New Holland (Australia). Fitzinger (1867, vol 3: 43) accepted the name "Canis novaehiberniae" and listed earlier synonyms. Studer (1880: 69-70) drew on the description by J. R. C. Quoy and J. P. Gaimard, zoologists on expeditions led by Louis de Freycinet and J. Dumont d'Urville, in naming the "house dog of the Papuans of the Bismarck Archipelago" as "Canis Hiberniae Quoy and Gaimard" though current nomenclatural rules attribute authorship to Studer (1880). Studer's paper included two photographs of a cranium (1880: 77). In a later detailed analysis of relationships between "prehistoric" and "present day" dogs, Studer (1901: 34-35) referred the New Ireland dog to "Canis Novae Hiberniae Lesson", apparently having realized that $C$. hiberniae was a junior synonym of that name. Measurements taken from an "unfortunately defective skull" suggested to Studer that this dog was a "direct relative" of "Stone Age" forms from Europe, Northwest America and Asia (1901: 35).

In 1884 , Germany took possession of the northeastern portion of the island of New Guinea (Kaiser-Wilhelmsland) and, in 1885, islands of the Bismarck Archipelago (New Britain and New Ireland) and northern Solomons (Bougainville, Fig. 1). In 1914, at the outbreak of WWI, Australia took possession of German New Guinea which, in 1921, became the Mandated Territory of New Guinea and later, in 1971, combined with the Australian Territory of Papua as Papua New Guinea. After 1914, most commentary on dogs from New Guinea is written in English and references to earlier French and German contributions fade from view. The primary exception is found in the work of Luomala (1960) on the Polynesian dog. She discussed several relevant voyages of exploration and reported that Fitzinger (1867) used the name "Canis Novae Hiberniae" with reference to the observations of Forrest (1782) and Lesson \& Garnot (1826-1829). Werth (1944: 224) followed Studer in applying the name "Canis novaehiberniae Lesson", and Schultz-Westrum (2010: F33) wrote that "Studer had placed New Guinea lowland dogs under the species Canis novae hiberniae Lesson more than half a century before Troughton came up with his highland species Canis hallstromi" but made no further comment on the status of the former name.

\section{Discussion}

Troughton (1957) was not the first to propose a binomial name for dogs found in the New Guinea region. One hundred and thirty years earlier, the name Canis familiaris novaehiberniae (as "Canis novae-hyberniae", under "Canis familiaris L.") had been proposed by the French naturalist René-Primevère Lesson (1827a: 159). For the next century, Lesson's nomenclature and diagnosis was taken to refer to dogs from both mainland New Guinea and islands of the Bismarck Archipelago.

Troughton was apparently unaware of this earlier literature. His own opinion was that he had described and named a primitive dog that had been "forced to the seclusion of a mountainous habitat by a combination of hostile circumstances" (Troughton 1971: 93). He asserted that the dogs he described had been obtained from "the remote Lavani Valley" in "uncontrolled Huri-Duna country" at 2,250-2,500 $\mathrm{m}$ above sea level, in what was then Southern Highlands District, Territory of Papua and New Guinea (Fig. 1). Available evidence suggests that the two dogs examined by Troughton did not come from Lavani Valley and were village-living rather than wild-living animals (Dwyer \& Minnegal, 2016: 2). Indeed, the older dog, a male, was owned by Medical Assistant Albert Speer and was offered to Edward Hallstrom so that it would be cared for when Speer returned from New Guinea to Australia on holiday.

It is likely that, at the time of European colonization of the New Guinea region, wild-living and village-living dogs comprised a single though heterogeneous gene pool (Dwyer \& Minnegal, 2016:9) and that, together with the dingo, they should be treated as "members of the dog parataxon Canis familiaris" (Jackson et al., 2017: 208). On that basis, the three names applied to dogs from the New Guinea region, Canis familiaris novaehiberniae Lesson, 1827, Canis familiaris papuensis Ramsay, 1879 and Canis hallstromi Troughton, 1957, would refer to the same biological entity, with novaehiberniae Lesson having priority. Conclusions reached in more recent studies of New Guinea dogs are jeopardized by failures to attend carefully to both the history of European discovery and the taxonomic literature of these animals.

ACKNOWLEDGEMENTS. The work of the late Katharine Luomala directed our attention to the New Ireland dog. Thanks also to Robin Hide for valued bibliographic help. 


\section{References}

Anon. 1957. N. Guinea dogs for Taronga. The Canberra Times 8 March 1957, p. 1. [Accessed 14 January 2021.]

https://trove.nla.gov.au/newspaper/article/91236096

Aplin, K. P., and E. Kale. 2011. The non-volant mammal fauna of the Muller Range, Papua New Guinea. In Rapid Biological Assessments of the Nakanai Mountains and the Upper Strickland Basin: Surveying the Biodiversity of Papua New Guinea's Sublime Karst Environments, ed. S. R. Richards and B. G. Gamui, pp. 211-221. Arlington, VA: Conservation International.

Crowther, M. S., M. Fillios, N. Colman, and M. Letnic. 2014. An updated description of the Australian dingo (Canis dingo Meyer, 1793). Journal of Zoology 293: 192-203.

https://doi.org/10.1111/jzo.12134

Deutscher. 1885. New Guinea. A trip among the islands. Yule Island. The Week (Brisbane, Qld.) 24 October 1885, p. 8.

https://trove.nla.gov.au/newspaper/article/181528967

Dwyer, P. D., and M. Minnegal. 2016. Wild dogs and village dogs in New Guinea: were they different? Australian Mammalogy 38: $1-11$.

https://doi.org/10.1071/AM15011

Dwyer, P. D., and M. Minnegal. 2021. Letter: Relationship between wild-living and village-living dogs in New Guinea. Proceedings of the National Academy of Sciences of the United States of America 118(12): e2020432118. https://doi.org/10.1073/pnas.2020432118

Eaton, P. 1991. Wetland management-traditional rights and recreational uses: the Tonda wildlife management area of Papua New Guinea. Landscape and Urban Planning 20: 67-72. https://doi.org/10.1016/0169-2046(91)90093-2

Fischer, J. B. 1829. Synopsis Mammalium. (Addenda, emendanda et index). J. G. Cottae: Stuttgardtiae. [Accessed 27 August 2021] https://archive.org/details/synopsismammalioofiscgoog

Fitzinger, L. J. 1867. Die Racen des Zahmen Hundes. Wien: kk Staatsdr. [Accessed 10 January 2021]

Flannery, T. F., and L. Seri. 1990. The mammals of southern West Sepik Province, Papua New Guinea: their distribution, abundance, human use and zoogeography. Records of the Australian Museum 42(2): 173-208. https://doi.org/10.3853/i.0067-1975.42.1990.114

Forrest, T. 1782. Reise nach Neuguinea und den molukkischen Inseln: nebst einer Beschreibung von Magindano, Sulu und andern Inseln. Hamburg: Carl Ernst Bohn.

Glaire, J. B. 1844. Chien, Canis. In Encyclopédie catholique, répertoire universel et raisonné des sciences, des lettres, des arts et des métiers, formant une bibliothèque universelle, Vol. 6, ed. J. B. Glaire and J.-A. Walsh (1839-1848), pp. 224-233. Paris: la Société de l'encyclopédie catholique. [Accessed 28 August 2021] https://gallica.bnf.fr/ark:/12148/bpt6k200812z/f230.image

Gollan, K. 1982. Prehistoric dingo. Unpublished PhD thesis: Australian National University. https://doi.org/10.25911/5d6cfce36fe39

Goodale, J. C. 1995. To Sing with Pigs is Human: The Concept of Person in Papua New Guinea. Seattle: University of Washington Press.

Guppy, H. B. 1887. The Solomon Islands and Their Natives. London: Swan Sonnenschein, Lowrey. https://doi.org/10.5962/bhl.title.33394

Helgen, K. M. 2007. The mammal fauna of the Kaijende Highlands, Enga Province, Papua New Guinea. In A Rapid Biodiversity Assessment of the Kaijende Highlands, Enga Province, Papua New Guinea, ed. S. J. Richards, pp. 52-68. Arlington, VA: Conservation International.

Hitchcock, G. 2004. Wildlife is Our Gold: Political Ecology of the Torassi River borderland, Southwest Papua New Guinea. Unpublished $\mathrm{PhD}$ thesis: University of Queensland.

https://pacific-data.sprep.org/system/files/18 12.pdf
ICZN. 1999. International Code of Zoological Nomenclature, 4th edn. London: International Trust for Zoological Nomenclature. https://www.iczn.org/the-code/the-code-online/

Jackson, S., and C. Groves. 2015. Taxonomy of Australian Mammals. Melbourne: CSIRO Publishing. https://doi.org/10.1071/9781486300136

Jackson, S. M., C. P. Groves, P. J. S. Fleming, K. P. Aplin, M. D. B. Eldridge, A. Gonzalez, and K. M. Helgen. 2017. The wayward dog: is the Australian native dog or Dingo a distinct species? Zootaxa 4317(2): 201-224. https://doi.org/10.11646/zootaxa.4317.2.1

Jukes, J. B. 1847. Narrative of the Surveying Voyage of H.M.S. Fly, Commanded by Captain F. P. Blackwood, R.N., in Torres Strait, New Guinea, and Other Islands of the Eastern Archipelago, During the Years 1842-1846: Together with an Excursion into the Interior of the Eastern Part of Java. Volume 1. London: T. \& W. Boone. https://doi.org/10.5962/bhl.title.96947

Koler-Matznick, J., I. L. Brisbin Jr, and M. Feinstein. 2005. An ethogram for the New Guinea Singing (Wild) Dog (Canis hallstromi), 3/2005. USA: The New Guinea Singing Dog Conservation Society. [Accessed 10 January 2021.]

Koler-Matznick, J., I. L. Brisbin Jr, M. Feinstein, and S. Bulmer. 2003. An updated description of the New Guinea singing dog (Canis hallstromi Troughton, 1957). Journal of Zoology 261: 109-118. https://doi.org/10.1017/S0952836903004060

Koler-Matznick, J., B. C. Yates, S. Bulmer, and I. L. Brisbin Jr. 2007. The New Guinea singing dog: its status and scientific importance. Australian Mammalogy 29: 47-56.

https://doi.org/10.1071/AM07005

Laurillard, C. L. 1849. Chien, Canis, Linn. MAM. In Dictionnaire universal d'Histoire naturelle, vol. 3 (Nouvelle edition - revue, considérablement augmentée et enrichie), ed. C. D. D'Orbigny, pp. 617-641. Paris: Abel Pilon. [Accessed 10 January 2021.] https://www.biodiversitylibrary.org/item/79921

Lawrence, D. R. 2014. The Naturalist and his 'Beautiful Islands': Charles Morris Woodford in the Western Pacific. Canberra: Australian National University Press. https://doi.org/10.22459/NBI.10.2014

Lesson, R.-P. 1827a. Manuel de mammalogie, ou histoire naturelle des mammifères. Paris: J. B. Bailliere et Fils. https://doi.org/10.5962/bhl.title.137811

Lesson, R.-P., 1827b. Chapitre 2. Considérations générales sur quelques mammifères. In Zoologie tome 1, part 1, ed. R.-P. Lesson and P. Garnot, pp. 117-136, in Voyage autour du monde... sur la Corvette... La Coquille, etc., ed. L. I. Duperrey (18261834). Paris: Arthus Bertrand. [Accessed 10 January 2021.] https://www.biodiversitylibrary.org/item/119030\#page/9/

Lesson, R.-P., and P. Garnot. 1826-1829. Zoologie. In Voyage autour du monde ... sur la Corvette... La Coquille, etc., ed. L. I. Duperrey (1826-1834). Paris: Arthus Bertrand. [Accessed 10 January 2021.] https://doi.org/10.5962/bhl.title.57936

Linnaeus, C. 1758. Systema Naturae per regna tria naturae, secundum classes, ordines, genera, species, cum characteribus, differentiis, synonymis, locis. Editio decima, reformata. Tome 1. Holmiae: Laurentii Salvii. https://doi.org/10.5962/bhl.title.542

Luomala, K. 1960. A history of the binomial classification of the Polynesian native dog. Pacific Science 14: 193-223. http://hdl.handle.net/10125/8347

Macgregor, W. M. 1892-1893. Annual Report, British New Guinea, from 1st July, 1891 to 30th June, 1892. Brisbane: Government Printer. [Accessed 30 August 2021.] https://nla.gov.au/nla.obj-84330873/

McIntyre, J. K., L. Wolf, B. N. Sacks, J. Koibur, and I. L. Brisbin Jr. 2019. A population of free-living highland wild dogs in Indonesian Papua. Australian Mammalogy 42: 160-166. https://doi.org/10.1071/AM18039 
Meyer, F. A. A. 1793. Systematisch-summarische Uebersicht der neuesten zoologischen Entdeckungen in Neuholland und Afrika. Nebst zwey andern zoologischen Abhandlungen. Leipzig: Dykischen Buchhandlung.

https://doi.org/10.5962/bhl.title.39685

Miklouho-Maclay, N. 1881. Remarks about the circumvolutions of the cerebrum of Canis dingo. Proceedings of the Linnean Society of New South Wales 6: 624-626.

https://doi.org/10.5962/bhl.part.11886

Miklouho-Maclay, N. 1975. Mikloucho-Maclay: New Guinea Diaries 1871-1883. Trans. C. L. Sentinella. Madang: Kristen Press.

Moresby, J. 1874-1875. Discoveries in Eastern New Guinea, by Captain Moresby and the Officers of H. M. S. Basilisk. Proceedings of the Royal Geographical Society of London 19(3): 225-244.

https://doi.org/10.2307/1799940

Morrant, D. S., C. N. Johnson, J. R. A. Butler, and B. C. Congdon. 2017a. Biodiversity friend or foe: Home range, habitat use and activity patterns of a top predator, the dingo in contested landscapes of the Australian Wet Tropics. Austral Ecology 42: 252-264.

https://doi.org/10.1111/aec.12427

Morrant, D. S., C. M. Wurster, C. N. Johnson, J. R. A. Butler, and B. C. Congdon. 2017b. Prey use by dingoes in a contested landscape: Ecosystem service provider or biodiversity threat? Ecology and Evolution 7: 8927-8935.

https://doi.org/10.1002/ece3.3345

Morton, A. 1885. Notes on New Guinea. The Mercury 31 March 1885 , p. 4. [Accessed 10 January 2021]

https://trove.nla.gov.au/newspaper/article/9102735

Murray, J. H. P. 1912. Papua or British New Guinea. London: T. Fisher Unwin. [Accessed 30 August 2021.]

http://gutenberg.net.au/ebooks12/1202531h.html

Parnaby, H. E., S. Ingleby, and A. Divljan. 2017. Type specimens of non-fossil mammals in the Australian Museum, Sydney. Records of the Australian Museum 69(5): 277-420. https://doi.org/10.3853/j.2201-4349.69.2017.1653

Ramsay, E. P. 1879. Contributions to the zoology of New Guinea. Parts I and II. Proceedings of the Linnean Society of New South Wales 3: 241-305.

https://doi.org/10.5962/bhl.part.22241

Schreber, J. C. D., G. A. Goldfuss, and J. A. Wagner. 1841. Die Säugthiere in Abbildungen nach der Natur, mit Beschreibungen; Supplement Abt. 2. Erlangen: Expedition des Schreber'schen säugthier- und des Esper'schen Schmetterlingswerkes... [Accessed 10 January 2021.]

https://www.biodiversitylibrary.org/item/97336\#page/5/

Schultze-Westrum, T. 2010. Papuan dogs-footnotes and research papers. [Accessed 13 January 2021.] http://www eco-communications. net/2010/11/22

Smith, B. P., K. M. Cairns, J. W. Adams, T. M. Newsome, M. Fillios, E. C. Déaux, W. C. H. Parr, M. Letnic, L. M. Van Eeden, R. G. Appleby, C. J. A. Bradshaw, P. Savolainen, E. G. Ritchie, D. G. Nimmo, C. Archer-Lean, A. C. Greenville, C. R. Dickman, L. Watson, K. E. Moseby, T. S. Doherty, A. D. Wallach, D. S. Morrant, and M. S. Crowther. 2019. Taxonomic status of the Australian dingo: the case for Canis dingo Meyer, 1793. Zootaxa 4564(1): 173-197.

https://doi.org/10.11646/zootaxa.4564.1.6

Stevens, H. N. ed. 1930. New Light on the Discovery of Australia: As Revealed by the Journal of Captain Don Diego de Prado y Tovar. London: Stevens and Stiles. [Accessed 30 August 2021.] http://gutenberg.net.au/ebooks09/0900011h.html

Strong, W. M. 1919. Some Personal Experiences in British New Guinea. The Journal of the Royal Anthropological Institute of Great Britain and Ireland 49: 292-308. https://doi.org/10.2307/2843445
Studer, T. 1880. Beitrag zur Kenntniss der Hunderacen in den Pfahlbauten. Archiv für Anthropologie: Zeitschrift für Naturgeschichte und Urgeschichte des Menschen 12(IV): 67-78. [Accessed 10 January 2021.]

https://archive.org/details/bub_gb_H307AQAAMAAJ/page/n84/mode/1up

Studer, T. 1901. Die prähistorischen Hunde in ihrer Beziehung zu den gegenwärtig lebenden Rassen. Abhandlungen der Schweizerischen Paläontologischen Gesellschaft 28: 1-137. [Accessed 14 January 2021.]

http://publikationen.ub. uni-frankfurt.de/frontdoor/index/index/year/2011/docld/5947

Surbakti, S., H. G. Parker, J. K. McIntyre, H. K. Maury, K. M. Cairns, M. Selvig, M. Pangau-Adam, A. Safonpo, L. Numberi, D. Y. P. Runtuboia, B. W. Davis, and E. A. Ostrander. 2020. New Guinea highland wild dogs are the original New Guinea singing dogs. Proceedings of the National Academy of Sciences of the United States of America 117: 24369-24376. https://doi.org/10.1073/pnas.2007242117

Troughton, E. 1957. A new native dog from the Papuan Highlands. Proceedings of the Royal Zoological Society of New South Wales 1955-1956: 93-94. https://www.biodiversitylibrary.org/page/38772848\#page/95

Troughton, E. 1971. The early history and relationships of the New Guinea Highland dog (Canis hallstromi). Proceedings of the Linnean Society of New South Wales 96: 93-98. https://www.biodiversitylibrary.org/page/34948042\#page/121/

UNDP (United Nations Development Program in Papua New Guinea). 2017. New species of orchids found in Papua New Guinea's mountains, Jan 12, 2017, pp. 4-5. [Accessed 10 January 2021.]

Voorhoeve, C. L. 1975. Languages of Irian Jaya Checklist. Pacific Linguistics, Series B, 31: 1-129.

https://openresearch-repository.anu.edu.au/bitstream/1885/146481/1/PL-B31.pdf

Walther, F. L. 1817. Der Hund, seine verschiedenen Zuchten und Varietäten, Geschichte seiner Verbreitung und Schicksale, Erziehung, Benutzung, Krankheiten und Feinde. Giessen: Heyer. [Accessed 17 January 2021.] http://mdz-nbn-resolving.de/urn:nbn:de:bvb:12-bsb10299571-3

Werth, E. 1944. Die primitiven Hunde und die Abstammungsfrage des Haushundes. Zeitschrift für Tierzüchtung und Züchtungsbiologie 56(3): 213-260. https://doi.org/10.1111/i.1439-0388.1944.tb01000.x

Williams, C. L., S. M. Mazzola, G. Curone, and G. Q. Pastorino. 2018. What we have lost: domestic dogs of the ancient South Pacific. Annual Research \& Review in Biology 25(2): 1-11. https://doi.org/10.9734/ARRB/2018/40377

\section{Endnote}

1 Wild-living dogs have been reported from scattered locations at high altitudes of the central mountain chain of New Guinea (Aplin \& Kale, 2011; Helgen, 2007; McIntyre et al., 2019), from Tonda Wildlife Park in southwest Papua New Guinea (Eaton, 1991; Hitchcock, 2004: 124) and from New Britain (Goodale, 1995: 5, UNDP, 2017). There are, in addition, late 19th century records of wild-living dogs from Yule Island, $100 \mathrm{~km}$ northwest from Port Moresby, from "bush in the interior of Alu" (Shortland Island, northern Solomons) and from higher altitudes of Mount Popomanaseu, Guadalcanal (Deutscher, 1885; Guppy, 1887; Lawrence, 2014: 110). On the New Guinea mainland, there are no reports of populations of wild-living dogs from low or middle-altitude areas that are dominated by rainforest and lightly populated by people. New Guinea dogs may be uncommon in low and middle-altitude rainforest of mainland New Guinea because, as for dingoes in north Queensland, these forests are unattractive as foraging habitats (Morrant et al., 2017a,b). 